\title{
Induce the plant resistance to pathogen infection
}

\author{
Ezzat, A. ${ }^{\text {a,b }}$., Z. Szabó, Z . ${ }^{a}$ \& Nyéki, J. ${ }^{\text {a }}$ \\ ${ }^{a}$ Institute of Horticulture, University of Debrecen, H-4015 P. O Box. 36. Debrecen, Hungary \\ ${ }^{b}$ Horticulture Department, Faculty of Agriculture, University of Kafelelsehikh, Egypt
}

\begin{abstract}
Summary: Systemic acquired resistance (SAR) is a mechanism of induced defense that confers long-lasting protection against a broad spectrum of microorganisms. Salicylic acid (SA) is the signal molecule which is required for induce SAR and is associated with accumulation of pathogenesis-related proteins, which are thought to contribute to resistance. SA paly vital role in some related resistance gene expression in plant cell which have direct or indirect effect on pathogen growth as SA has direct toxicity for pathogen and in the same time has stimulation effect for some enzyme related to reduce the oxidative burst.
\end{abstract}

Keywords: SAR, salicylic acid, jasmonic acid

\section{Plant response to pathogen attack}

Plants are attacked by a variety of biotic stresses like fungal, bacterial, or viral infections. This lead to a great loss to plant yield. There are various ways to protect their crop from the disease. Some options include development of resistant cultivars, biological control, and chemical pesticides. Nearly all chemical pesticides or fungicides have a direct antibiotic principle. But their use at commercial level is uneconomical, application is cumbersome, and some are proved to be cancer reasons. Therefore, searching for some friendly environmental strategies to face such problems and in the same way to void health hazard is considered as the very important tend to new research topics (Gamal et al, 2007). In contrast to the influence of abiotic stressors or growth conditions (humidity and temperature) pathogenic attacks aren't the regular factors. Plants have to balance the costs and potential benefits of investing in defense in an environment where enemy attack is variable. It means that besides the basic, constitutively maintained level of the resistance to high variety of pathogens "permanent costs", plants evolved specific mechanisms of the resistance against the aggressive forms, triggered by the early detection of the enemy. This priming results in faster and stronger inducer of defense mechanisms after detecting pathogen attack, and this effect can be observed for a long time. Plants have many types of resistance strategies depending on the type of pathogen atacked (Garcia et al., 2006). salicylic acid (SA) dependent response is activated by biotrophic pathogens whereas jasmonic acid (JA) and ethylene dependent responses seem to be initiated by necrotrophs.

In plants, many complex discipline of defense response is induced after detection of microorganism via recognition of elicitor molecules released during plant-pathogen interaction. Despite the diversity of these constitutive defenses, many microbes succeed in breaking through this pre-invasive layer of defense. However, a broad spectrum of inducible plant defenses can be work to limit further pathogen ingress. For this post-invasive line of defense, plants have evolved sophisticated strategies to perceive their attacker and to translate this perception into an effective immune response.

1. The primary immune response recognizes common features of microbial pathogens. These microbial signal or determinate are referred to as pathogen-associated molecular patterns (PAMPs) ${ }^{19}, 20,22$. PAMPs activate pattern-recognition receptors (PRRs) in plant, which trigger different downstream signaling events that $t$ the end result in the activation of a basal resistance that is called PAMP-triggered immunity (PTI; Fig. 1a) (Göhre and Robatzek, 2066, Jones \& Dangl, 2006, Nürnberger \& Kemmerling, 2009).

2. For the virulence pathogen, they acquired effector molecules that are transported into the host cell to suppress PTI and promote virulence of the pathogen, resulting in effector-triggered susceptibility (ETS; Fig. $1 b$ ).

3. plants acquired resistance $(\mathrm{R})$ proteins that recognize these attacker-specific effectors, resulting in a secondary immune response called effector-triggered immunity (ETI; Fig. 1c) (Chisholm et al., 2006)

Ultimately, the final outcome depends on the balance between the ability of the pathogen to suppress the plant's immune system and the capacity of the plant to recognize the pathogen and to activate effective defenses.

Understanding of some elicitors mechanisms reported that the activation of signal transduction pathways generally related to production of many substances which possess antimicrobial properties as active oxygen species (AOS), phytoalexin biosynthesis, reinforcement of plant cell wall associated with phenyl propanoid compounds, deposition of callose, synthesis of defense enzymes, and the accumulation of pathogenesis-related (PR) proteins,(Van and Strien 1999). 
a

\section{PAMP-triggered immunity}

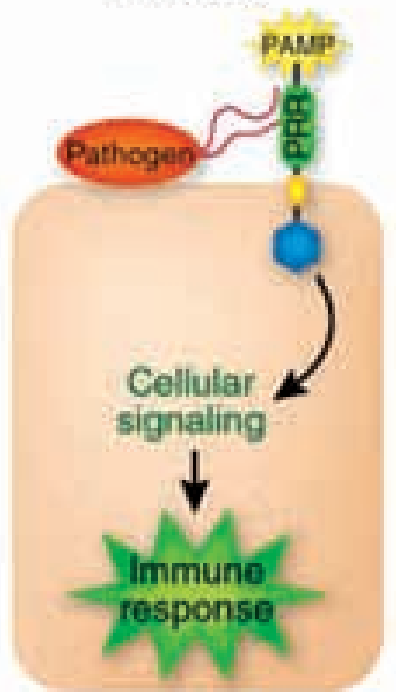

b

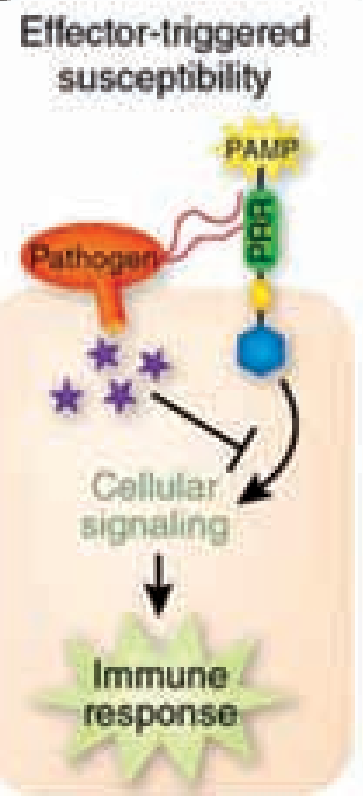

C

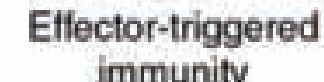
immunity

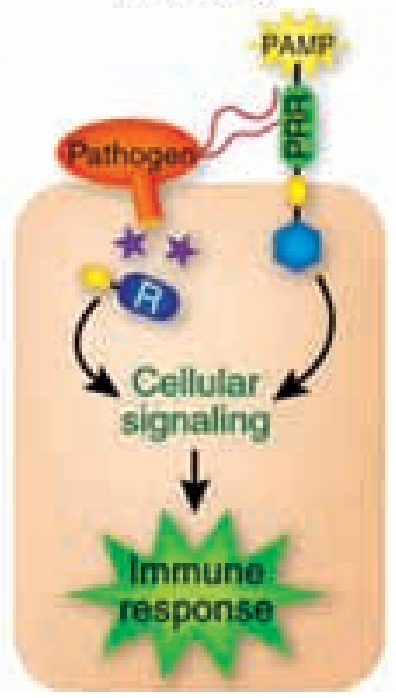

Figure 1. Simplified schematic representation of the plant immune system (a) Upon pathogen attack, pathogen-associated molecular patterns (PAMPs) activate pattern-recognition receptors (PRRs) in the host, resulting in a downstream signaling cascade that leads to PAMP-triggered immunity (PTI)19. (b) Virulent pathogens have acquired effectors (purple stars) that suppress PTI, resulting in effector-triggered susceptibility (ETS). (c) In turn, plants have acquired resistance (R) proteins that recognize these attacker-specific effectors, resulting in a secondary immune response called effector-triggered immunity (ETI) (Corné et al 2009

\section{Reactive Oxygen Species (ROS)}

AOS production leads to hypersensitive response (HR) (Agrios, 1988) in plants which is a mechanism, used by plants, to prevent the spread of infection by microbial pathogens. The HR is characterized by the rapid death of cells in the local region surrounding an infection. The HR serves to restrict the growth and spread of pathogens to other parts of the plant. The HR is analogous to the innate immune system found in animals, and commonly precedes a slower systemic (whole plant) response, which ultimately leads to systemic acquired resistance (SAR). (Heil and Bostock 2002).

Doke (13) was the first who reported on the rapid generation of ROS during plant-pathogen interactions was by in Phytophthora infestans-potato interaction. In studies involving bacteria and cell suspensions, there are two phases of ROS production, termed as "oxidative burst". Phase 1 is rapid, transient, and nonspecific, whereas phase 2 occurs later and yields a much higher concentration of ROS (Baker et al 1991).

Some initial reactions are the prerequisite for initiation of the signaling network that will trigger the overall defense response [Hammond and Jones, 1996]. Such as the opening of specific ion channels across the plasma membranes, the rapid production of AOS, such as and $\mathrm{H} 2 \mathrm{O} 2$, known as the oxidative burst or phosphorylation or dephosphorylation of specific proteins (Conrath et al., 1997).

In most systems $\mathrm{H}_{2} \mathrm{O}_{2}$ appears to be the major ROS that accumulates. Under physiological conditions, the first

reduction of $\mathrm{O}_{2}$ forms the superoxide anion $\left(\mathrm{O}_{2}^{-}\right)$and hydroperoxyl radical $\left(\mathrm{HO}_{2}{ }^{-}\right)$, the second step forms hydrogen peroxide $\left(\mathrm{H}_{2} \mathrm{O}_{2}\right)$, and the third step produces hydroxyl radical $\left(\mathrm{HO}^{\circ}\right)$. ( $\left.\mathrm{HO}^{*}\right)$ and $\left(\mathrm{O}_{2}^{-}\right)$possess very short half-lives. Uncharged $\mathrm{H}_{2} \mathrm{O}_{2}$ is more stable, whereas cannot migrate in solution and instead reacts locally, notably with molecular targets by modifying their structure and activity. $\mathrm{H}_{2} \mathrm{O}_{2}$ as well as can react with polyunsaturated lipids in membranes forming lipid peroxides, which can lead to biological membrane destruction [Grant and Loake, 2000].

Under stress conditions the cells produce ROS species such as $\mathrm{HO}^{\circ}$, $\mathrm{O}_{2}^{-}$, and $\mathrm{H} 2 \mathrm{O} 2$ and they are strong oxidizing species that can rapidly attack all types of biomolecules and damage. The cells protect them for the protection from oxidative damage; the cells can express both oxygen radical detoxifying enzymes such as catalase (CAT), peroxidase (POD), and superoxide dismutase (SOD), and nonenzymatic antioxidants such as ascorbate peroxidase and glutathione-S-transferase (Pnueli et al, 2003). These enzymes play a crucial role in the protection of plant cells from oxidative damage at the sites of enhanced ROS generation [56]. The cooperative function of these antioxidants plays an important role in scavenging ROS and maintaining the physiological redox status of organisms (Cho and Seo, 2005).

\section{Induced Resistance (IR) of Fruits}

The traditional postharvest disease control is often by the application of synthetic fungicides (Eckert and Ogawa, 1988). However, chemical protection is discouraged due to problems related to fungicide toxicity, development of fungicide resistance by pathogens, and potential harmful effects on the environment and human health, alternatives to synthetic chemicals have been proposed (Eckert et al., 1994; Tian and Fan, 2000; Elad et al., 2004). The use of biologically based fungicides in conjunction with induced resistance (IR) was suggested as a feasible approach for reducing postharvest disease in harvested fruits and vegetables (Cook et al., 1999; Tian et al., 2001).

IR defined as Enhancement of resistance of a susceptible plant in response to an extrinsic stimulus, the stimulus being of a biotic or abiotic nature. The enhanced resistance can be localized at the site of the inducing treatment or it can be systemic IR is a response which diverts carbon and nitrogen resources from plant growth and reproduction to provide a 
long lasting and systemic resistance to a broad spectrum of pathogens and pests (Linda, 2001). Two types of IR.

1. Systemic acquired resistance (SAR) is an active defense initiated by infection with certain necrotizing pathogens and confers resistance to secondary infection. SAR is effective against a broad-spectrum of pathogens including viruses, bacteria, fungi, and oomycetes (Ryals et al., 1996; Sticher et al., 1997). Inhibition of salicylic acid (SA) accumulation or biosynthesis impairs SAR (Gaffney et al., 1993).

2. Induced systemic resistance (ISR) resembles SAR but is induced by root colonization of specific strains of non-pathogenic plant growth-promoting rhizobacteria in contrast to SAR that is induced by necrotizing pathogens. Unlike SAR, ISR is dependent on jasmonate and ethylene, independent on SA and not associated with $P R$ gene expression (van Loon, 1997). Molecularly, both SAR and ISR in Arabidopsis are intertwined through NPR1 gene (Figure 2).
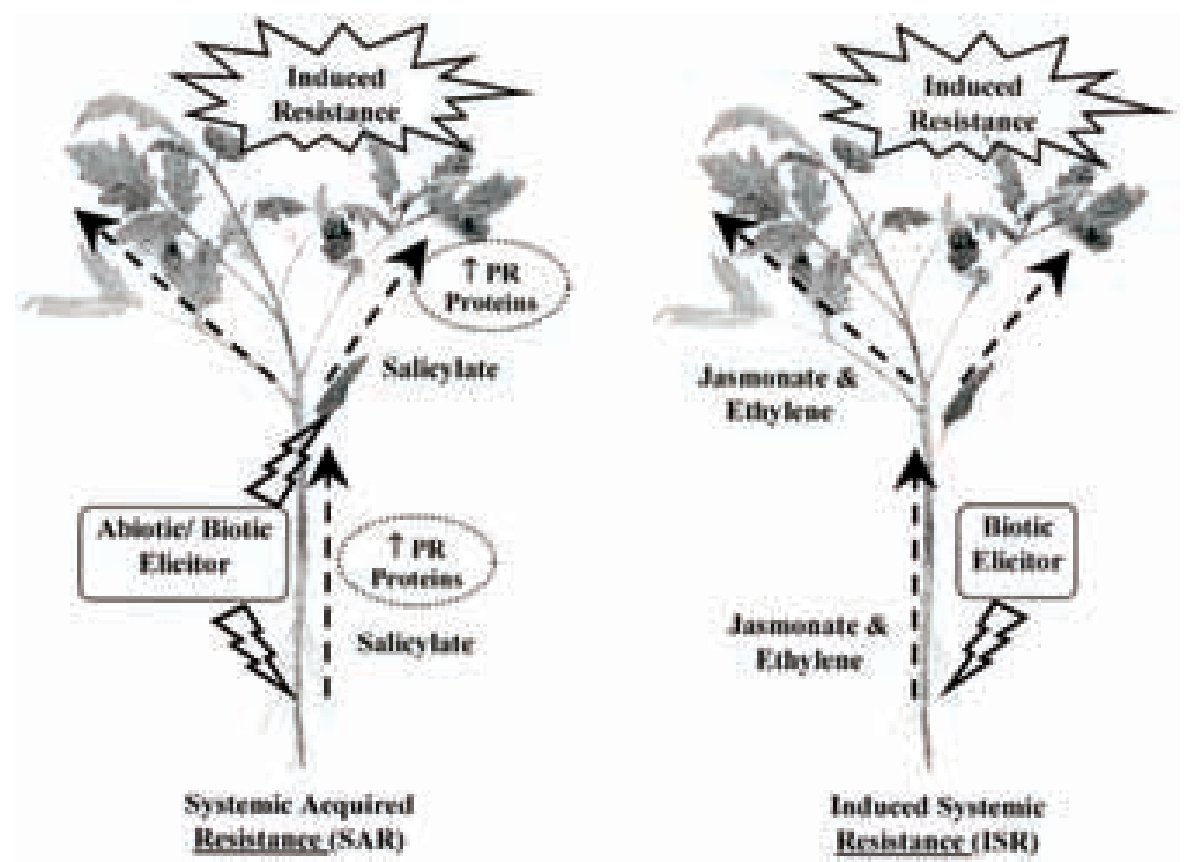

Figure 2. Signal transduction pathways for systemic acquired resistance (SAR) and induced systemic resistance (ISR). Source (Vallad and Goodman, 2004).

IR can be triggered in fruits by:

- Microbial or biological agents (non-pathogens, avirulent forms of pathogens).

- Physical agents (curing, $\gamma$-radiation, hot water brushing and UV-C light).

- certain chemical agents [DL-3-amino butyric acid (BABA), 1,2,3-benzothiadiazole-7-carbothioic acid S-methyl ester (ASM), salicylic acid (SA), ethylene, harpin, 2,6-dichloroisonicotinic acid, jasmonic acid (JA), methyl jasmonate (MJ), Oxalic acid (OA), potassium and phosphates]

- Natural compounds (Chitosan and Margosan-O) (Tian and Chan, 2004). In many experiments, IR holds promise as a new technology for the control of postharvest diseases and has been proven to be effective in the laboratory and in a few field cases (Droby et al., 2001; El-Ghaouth et al., 2003; Chan et al., 2008). Mechanisms of IR have been wellcharacterized from cell structure, physiological, and biochemical changes. Proteomic studies shed a light on molecular changes of IR

\section{Systemic Acquired Resistance (SAR)}

The systemic acquired resistance (SAR) is a «wholeplant» resistance response that occurs following an earlier localized exposure to a pathogen. SAR is analogous to the innate immune system found in animals, and there is evidence that SAR in plants and innate immunity in animals may be evolutionarily conserved. Plants use pattern-recognition receptors to recognize conserved microbial signatures. This recognition triggers an immune response. The first plant receptors of conserved microbial signatures were identified in rice (Song, 1995) $)^{[1]}$ and in Arabidopsis (Gomez-Gomez, 2000).

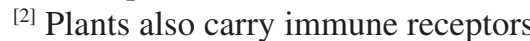
that recognize highly variable pathogen effectors. SAR is important for plants to resist disease, as well as to recover from disease once formed. SAR can be induced by a wide range of pathogens, especially (but not only) those that cause tissue necrosis, and the resistance observed following induction of SAR is effective against a wide range of pathogens, which is why SAR resistance is sometimes called „broad spectrum.” SAR is associated with the induction of a wide range of genes (so called PR or „pathogenesis-related” genes), and the activation of SAR requires the accumulation of endogenous salicylic acid (SA). The pathogen-induced SA signal activates a molecular signal transduction pathway that is identified by a gene called NIM1, NPRI or SAII (three names for the same gene) in the model genetic system Arabidopsis thaliana. SAR has been observed in a wide range of flowering plants, including dicotyledon and monocotyledon species.

\section{Events associated with SAR}

The onset of SAR in noninfected plant organs is triggered by the phloem mobile signal which is released following pathogen infection. The signal travels throughout the plant and transduced in target tissues. Following signal transduction, 
resistance is maintained for several days and weeks and this is likely due to de novo gene expression. The biochemical changes that occur during SAR can be divided into two phases, that is, initiation and maintenance. Physiological changes during initiation phase may be transient and short lived, but during maintenance a quasi steady state should exist.

\section{Elicitors and Their Mode of Action}

Originally Elicitors, in biology, are compounds that when introduced into living organisms signal the activation or synthesis of another compound. Effectors differ from hormones, compounds produced in one part of an organism to cause a change in another part of that organism, in that they do not have to be produced within the organism that they are eliciting a response in, and are usually not naturally occurring in the organism (Ebel and Cosio, 1994, Hahn, 1996, Nürnberger, 1999 and Boller 199). Eventually, the induction of defense responses may lead to enhanced resistance. This broader definition of elicitors includes both substances of pathogen origin (exogenous elicitors) and compounds released from plants by the action of the pathogen (endogenous elicitors). Elicitors are classified as physical or chemical, biotic or abiotic, and complex or defined depending on their origin and molecular structure (Table 1).

Table 1: List of elicitors used and their effects on different plant species

\begin{tabular}{|c|c|c|c|c|}
\hline No. & Plant & $\begin{array}{c}\text { Type of } \\
\text { elicitor } \\
\text { used }\end{array}$ & Effects & References \\
\hline 1 & $\begin{array}{l}\text { Brassica } \\
\text { napus }\end{array}$ & $\begin{array}{l}\text { Methyl } \\
\text { jas- } \\
\text { monate }\end{array}$ & $\begin{array}{l}\text { Accumulation of indolyl glu- } \\
\text { cosinolates in the leaves. The } \\
\text { predominant components of the } \\
\text { response were 3-indolylmethyl- } \\
\text { and 1-methoxy-3-indolylmeth- } \\
\text { ylglucosinolates, which together } \\
\text { comprised } 90 \% \text { of the total } \\
\text { glucosinolates in treated leaves. }\end{array}$ & $\begin{array}{l}\text { [Doughty } \\
\text { e al., } \\
\text { 1995] }\end{array}$ \\
\hline 2 & $\begin{array}{l}\text { Citrus } \\
\text { sinensis }\end{array}$ & $\begin{array}{l}\beta \text {-amino } \\
\text { butyric } \\
\text { acid }\end{array}$ & $\begin{array}{l}\text { Inhibited Penicillium italicum } \\
\text { spore germination and germ tube } \\
\text { elongation in vitro. Involved in } \\
\text { the induced resistance against } \\
\text { Penicillium italicum. }\end{array}$ & $\begin{array}{l}\text { [Tavallali } \\
\text { et al., } \\
\text { 2008] }\end{array}$ \\
\hline 3 & $\begin{array}{l}\text { Sola- } \\
\text { num } \\
\text { me- } \\
\text { longena }\end{array}$ & $\begin{array}{l}\text { Salicylic } \\
\text { acid, } \\
\text { chitosan, } \\
\text { methyl } \\
\text { sali- } \\
\text { cylate, } \\
\text { and } \\
\text { methyl } \\
\text { jas- } \\
\text { monate }\end{array}$ & $\begin{array}{l}\text { Increased lignin deposition in cell } \\
\text { walls of roots, accumulation of } \\
\text { phenolics, increase in the activity } \\
\text { of enzymes PAL, POD, polyphe- } \\
\text { nol oxidase, cinnamyl alcohol } \\
\text { dehydrogenase, and catalase. } \\
\text { Provided resistance against } \\
\text { Ralstonia solanacearum. }\end{array}$ & $\begin{array}{l}\text { [Mandal } \\
\text { 2010] }\end{array}$ \\
\hline
\end{tabular}

\begin{tabular}{|c|c|c|c|c|}
\hline No. & Plant & $\begin{array}{l}\text { Type of } \\
\text { elicitor } \\
\text { used }\end{array}$ & Effects & References \\
\hline 4 & $\begin{array}{l}\text { Pha- } \\
\text { seolus } \\
\text { vulgaris }\end{array}$ & $\begin{array}{l}\text { Salicylic } \\
\text { acid and } \\
\text { Methyl } \\
\text { jas- } \\
\text { monate }\end{array}$ & $\begin{array}{l}\text { Controlled spider mite infestation, } \\
\text { improved plant growth and bean } \\
\text { yield. }\end{array}$ & $\begin{array}{l}\text { [Farouk } \\
\text { and } \\
\text { Osman } \\
2011]\end{array}$ \\
\hline 5 & $\begin{array}{l}\text { Brassica } \\
\text { species }\end{array}$ & $\begin{array}{l}\text { Salicylic } \\
\text { acid }\end{array}$ & $\begin{array}{l}\text { Recovery from heat stress, } \\
\text { increased seedling length, reduced } \\
\text { electrolyte leakage, and enhanced } \\
\text { membrane protection. Increased } \\
\text { level of total soluble sugars, } \\
\text { fresh/dry weight, and enzymatic } \\
\text { activities of invertase, catalase, } \\
\text { and peroxidase conferred thermo- } \\
\text { tolerance. Enhanced expression of } \\
\text { some new proteins including heat } \\
\text { shock proteins (HSPs) was also } \\
\text { observed. }\end{array}$ & $\begin{array}{l}\text { [Kaur et } \\
\text { al., 2009] }\end{array}$ \\
\hline
\end{tabular}

Source: Thakur and Singh, 2013

\section{References}

A. Garcia-Brugger, O. Lamotte, E. Vandelle et al., (2006): Early signaling events induced by elicitors of plant defenses, Molecular Plant-Microbe Interactions, vol. 19. (7): 711-724.

C. J. Baker, N. R. O'Neill, L. D. Keepler, and E. W. Orlandi, (1991): Early responses during plant- bacteria interactions in tobacoo cell suspensions, Phytopathology, 81: 1504-1507.

Chan, Z. L., Wang, Q., Xu, X. B., Meng, X. H., Xu, Y., Qin, G. Z., et al. (2008): Functions of defense-related proteins and dehydrogenases in resistance response induced by salicylic acid in sweet cherry fruits at different maturity stages. Proteomics 8: 4791-4807.

Chisholm, S.T., Coaker, G., Day, B. \& Staskawicz, B.J. (2006): Host-microbe interactions: shaping the evolution of the plant immune response. Cell 124: 803-814.

Cook, D. W. M., Long, P. G., and Ganesh, S. (1999): The combined effect of delayed application of yeast biocontrol agents and fruit curing for the inhibition of the postharvest pathogen Botrytis cinerea in kiwifruit. Postharvest Biol. Technol. 16: 233-243.

Corné M J Pieterse, Antonio Leon-Reyes, Sjoerd Van der Ent \& Saskia C M Van Wees (2009): Networking by small-molecule hormones in plant immunity Nature Chemical Biology 5: 308-316.

Droby, S., Vinokur, V., Weiss, B., Cohen, L., Daus, A., Goldschmidt, E. E., et al. (2001): Induction of resistance to Penicillium digitatum by the yeast biocontrol agent Candida oleophila. Phytopathology. 92: 393-399.

Eckert, J. W., and Ogawa, J. M. (1988): The chemical control of vegetables and root tuber crops. Annu. Rev. Phytopathol. 26: 433-446.

Elad, Y., Williamson, B., Tudzynski, P., and Delen, N. (2004): Botrytis spp. and diseases they cause in agricultural systems- an introduction. in Botrytis: Biology, Pathology and Control, eds Y. Elad, B. Williamson, P. Tudzynski, and N. Delen (Dordrecht: Kluwer Academic Publishers), 1-8. 
El-Ghaouth, A., Wilson, C. L., and Wisniewski, M. (2003): Control of postharvest decay of apple fruit with Candida saitoana and induction of defense responses. Phytopathology. 93: 344-348.

Fan, Q., and Tian, S. P. (2000): Postharvest biological control of Rhizopus rot on nectarine fruit by Pichia membranefaciens Hansen. Plant Dis. 84: 1212-1216.

G. N. Agrios (1988): Plant Pathology, Academic Press, San Diego, Calif, USA, 3rd edition

Gaffney, T., Friedrich, L., Vernooij, B., Negrotto, D., Nye, G., Uknes, S., et al. (1993): Requirement of salicylic acid for the induction of systemic acquired resistance. Science 261: 754-756.

Gary E. Vallad a and Robert M. Goodman (2004): Systemic Acquired Resistance and Induced Systemic Resistance in Conventional Agriculture. Crop Science

Göhre, V. \& Robatzek, S. (2008): Breaking the barriers: microbial effector molecules subvert plant immunity. Annu. Rev. Phytopathol. 46: 189-215.

Gomez-Gomez, L. et al. (2000): FLS2: an LRR receptor-like kinase involved in the perception of the bacterial elicitor flagellin in Arabidopsis. Molecular Cell 5 (6): 1003-1011.

J. Ebel and E. G. Cosio (1994): Elicitors of plant defense responses, International Review of Cytology, 148: 1-36.

J. J. Grant and G. J. Loake (2000): Role of reactive oxygen intermediates and cognate redox signaling in disease resistance, Plant Physiology, 124. (1): 21-30.

J. W., Sievert, J. R., and Ratnayake, M. (1994): Reduction of imazalil effectiveness against citrus green mold in California packinghouse by resistant biotypes of Penicillium digitatum. Plant Dis. 78: 791-794.

Jones, J.D.G. \& Dangl, J.L. (2006): The plant immune system. Nature 444: 323-329.

K. E. Hammond-Kosack and J. D. G. Jones (1996): Resistance gene-dependent plant defense responses, The Plant Cell, 8. (10): 1773-1791.

K. J. Doughty, G. A. Kiddle, B. J. Pye, R. M. Wallsgrove, and J. A. Pickett (1995): Selective induction of glucosinolates in oilseed rape leaves by methyl jasmonate, Phytochemistry, 38. (2): 347-350.

L. C. Van Loon and E. A. Van Strien (1999): The families of pathogenesis-related proteins, their activities, and comparative analysis of PR-1 type proteins, Physiological and Molecular Plant Pathology, 55. (2): 85-97.

L. Pnueli, H. Liang, M. Rozenberg, and R. Mittler (2003): Growth suppression, altered stomatal responses, and augmented induction of heat shock proteins in cytosolic ascorbate peroxidase (Apx1)-deficient Arabidopsis plants, Plant Journal, 34. (2): 187203.

Linda, L. W. (2001): Induced resistance: from the basic to the applied. Trends Plant Sci. 6: 445-447.

M. G. Hahn (1996): Microbial elicitors and their receptors in plants, Annual Review of Phytopathology, 34: 387-412.

M. Heil and R. M. Bostock (2002): Induced systemic resistance (ISR) against pathogens in the context of induced plant defences, Annals of Botany, 89. (5): 503-512.

Meenakshi Thakur and Baldev Singh Sohal (2013): Role of Elicitors in Inducing Resistance in Plants against Pathogen Infection: A Review, ISRN Biochemistry.
N. Doke (1983): Involvement of superoxide anion generation in the hypersensitive response of potato tuber tissues to infection with an incompatible race of Phytophthora infestans and to the hyphal wall components, Physiological Plant Pathology, 23. (3): 345-357.

N. G. El-Gamal, F. Abd-El-Kareem, Y. O. Fotouh, and N. S. El Mougy (2007): Induction of systemic resistance in potato plants against late and early blight diseases using chemical inducers under greenhouse and field conditions, Research Journal of Agriculture and Biological Sciences, 3. (2): 73-81.

Nürnberger, T. \& Kemmerling, B. (2009): Pathogen-associated molecular patterns (PAMP) and PAMP-triggered immunity. Annu. Plant Rev. 34: 16-47.

P. Kaur, N. Ghai, and M. K. Sangha (2009): Induction of thermotolerance through heat acclimation and salicylic acid in Brassica species, African Journal of Biotechnology, 8. (4): 619-625.

Ryals, J. A., Neuenschwander, U. H., Willits, M. G., Molina, A., Steiner, H. Y., and Hunt, M. D. (1996): Systemic acquired resistance. Plant Cell 8: 1809-1819.

S. Farouk and M. A. Osman (2011): The effect of plant defense elicitors on common bean (Phaseolus vulgaris L.) growth and yield in absence or presence of spider mite (Tetranychus urticae Koch) infestation, Journal of Stress Physiology and Biochemistry, 7. (3): 5-22.

S. Mandal (2010): Induction of phenolics, lignin and key defense enzymes in eggplant (Solanum melongena L.) roots in response to elicitors, African Journal of Biotechnology, 9. (47): 8038-8047.

Song, W.Y. et al. (1995): „A receptor kinase-like protein encoded by the rice disease resistance gene, XA21. Science, 270. (5243): 1804-1806.

Sticher, L., Mauch-Mani, B., and Metraux, J. P. (1997): Systemic acquired resistance. Annu. Rev. Phytopathol. 35. 235-270.

T. Boller (1995): Chemoperception of microbial signals in plant cells, Annual Review of Plant Physiology and Plant Molecular Biology, 46:189-214.

T. Nürnberger (1999): Signal perception in plant pathogen defense, Cellular and Molecular Life Science, 55: 167-182.

Tian, S. P., and Chan, Z. L. (2004): Potential of induced resistance in postharvest diseases control of fruits and vegetables. Acta Phytopathol. sinica 234. 385-394.

Tian, S. P., Fan, Q., Xu, Y., and Wang, Y. (2001): Effects of Trichosporon sp. in combination with calcium and fungicide on biocontrol of postharvest diseases in apple fruits. Acta Bot. Sin. 43. 501-505.

U. Conrath, H. Silva, and D. F. Klessig (1997): Protein dephosphorylation mediates salicylic acid-induced expression of PR-1 genes in tobacco, Plant Journal, vol. 11. (4): 747-757.

U. H. Cho and N. H. Seo (2005): Oxidative stress in Arabidopsis thaliana exposed to cadmium is due to hydrogen peroxide accumulation, Plant Science, 168. (1): 113-120.

V. Tavallali, S. Karimi, S. Mohammadi, and S. Hojati (2008): Effects of $\beta$-aminobutyric acid on the induction of resistance to Penicillium italicum, World Applied Science Journal, 5. (3): 345-351.

van Loon, L. C. (1997): Induced resistance in plants and the role of pathogenesis- related proteins. Eur. J. Plant Pathol. 103. 753-765. 